\title{
Fitz-Hugh-Curtis Syndrome: A Diagnosis to Consider in a Woman with Right Upper Quadrant Abdominal Pain without Gallstones
}

\author{
Pietro Benedetto Faré, Ileana Allio, Rita Monotti, Fabrizio Foieni \\ Internal Medicine Department, Ospedale La Carità, Locarno, Switzerland
}

Received: $14 / 09 / 2017$

Accepted: 23/09/2017

Published: 05/12/2017

\begin{abstract}
How to cite this article: Faré PB, Allio I, Monotti R, Foieni F. Fitz-Hugh-Curtis syndrome: a diagnosis to consider in a woman with right upper quadrant abdominal pain without gallstones. EJCRIM 2017;4: doi:10.12890/2017_000743.
\end{abstract}

Conflicts of Interests: The Authors declare that there are no competing interests.

This article is licensed under a Commons Attribution Non-Commercial 4.0 License

\section{ABSTRACT}

Ayoung woman presented with right upper quadrant abdominal pain exacerbated by movement and breathing. Extensive evaluation revealed no gallstones or any other specific cause. Urine polymerase chain reaction results for Chlamydia trachomatis were positive, so the clinical diagnosis of Fitz-Hugh-Curtis syndrome was confirmed. This type of localized peritonitis is thought to be a complication of an ascending genital infection leading to pelvic inflammatory disease. The diagnosis is established on clinical grounds after excluding alternative, more common conditions. Proper antibiotic treatment usually leads to recovery and prevents long-term complications.

\section{LEARNING POINTS}

- Right upper quadrant pain in a sexually active woman may be due to Fitz-Hugh-Curtis syndrome, a type of localized peritonitis also called perihepatitis.

- This condition is considered to be a complication of an ascending genital infection leading to pelvic inflammatory disease.

- Sexually active women with right upper quadrant abdominal pain without gallstones should be tested for Chlamydia trachomatis and Neisseria gonorrhoeae.

\section{KEYWORDS}

Right upper quadrant abdominal pain; perihepatitis; Fitz-Hugh-Curtis syndrome

\section{CASE PRESENTATION}

A 23-year-old woman presented at our emergency department with a 2-week history of right upper quadrant abdominal pain. Her medical history was unremarkable, and she was taking an oestroprogestative contraceptive pill. She complained of a dull, moderate pain (4/10) with sharp, 'stabbing' exacerbations (8/10) when she ran or walked down the stairs and when she breathed deeply or coughed. A reproducible tenderness was evoked in the right upper quadrant with a Murphy's sign considered positive. C-reactive protein was elevated (106 mg/l), the white cell count was normal (leucocyte $6.0 \mathrm{G} / \mathrm{l}$ ) and there were no liver enzyme alterations. Ultrasound examination showed gallbladder distention without gallstones, and wall oedema or pericholecystic fluid. The biliary tree was not dilated (Fig. 1). Since the patient had ongoing abdominal pain, she was evaluated by the surgical team for suspicion of ectopic acute appendicitis. An abdomen CT scan did not identify intra-abdominal pathology. A young medical officer with experience in sexually transmitted diseases (STDs) proposed performing a urine polymerase chain reaction (PCR) test for Chlamydia trachomatis and Neisseria gonorrhoeae which was positive for the former. Consequently, the clinical diagnosis of Fitz-Hugh-Curtis syndrome (FHCS) was established. 
A pelvic examination by a gynaecologist revealed no signs of pelvic inflammatory disease (PID). The patient was treated with doxycycline and a single dose of ceftriaxone with rapid improvement and no relapses at follow-up.

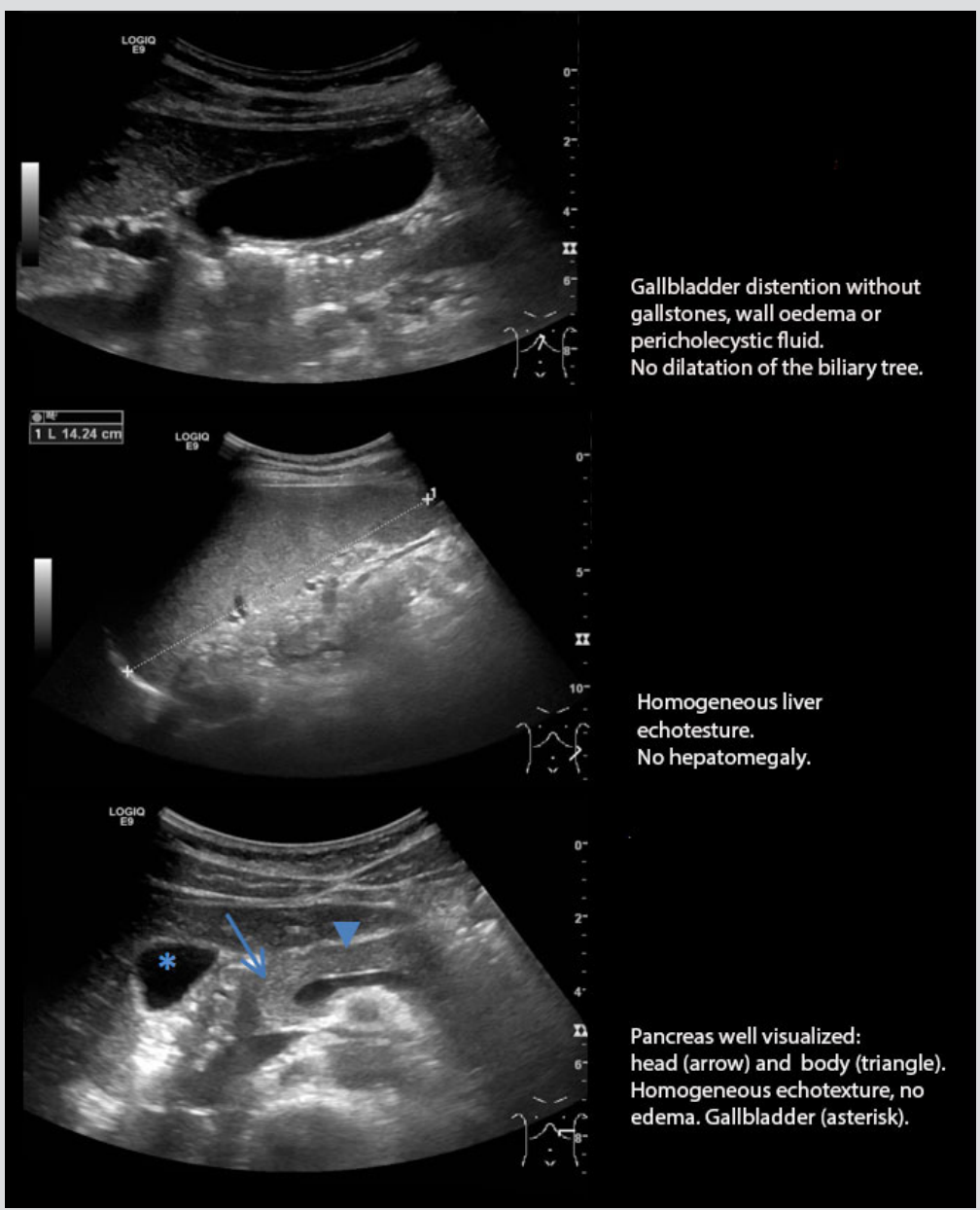

Figure 1. Abdominal ultrasonography

\section{DISCUSSION}

FHCS is localized inflammation of the peritoneum associated with an ascending genital infection ${ }^{[1-3]}$. Typical lesions are the so-called 'violin string adhesions', which are peritoneal adhesions between the diaphragm's right dome and the anterior surface of the liver capsule ${ }^{[4-3]}$. The liver itself is not involved, hence the term 'perihepatitis'. This condition is considered to be a complication of PID and sometimes may be its only sign. The cardinal symptom, right upper quadrant pain exacerbated by movement, may be subtle and sometimes can appear long before or long after PID. This quite uncommon complication, which is found in 4-27\% of women with PID according to different diagnostic criteria, is sometimes not recognized by inexperienced primary care physicians and so can be simply overlooked ${ }^{[1,5]}$.

The typical lesions ('violin string adhesions') can be easily visualized with a laparoscopic examination, but this is often not necessary since the diagnosis is made on clinical grounds. The main criteria are a suitable clinical context, the exclusion of other more common causes of right upper quadrant pain (Table 1) and microbiological demonstration of particular bacteria.

The patient's medical history is very important: the typical pattern of pain in a young woman, symptoms suggestive of present or previous STD, or STD risk factors, should elicit a high index of suspicion. The physical examination may help to confirm the typical clinical pattern, rule out other causes of right upper quadrant abdominal pain and identify symptoms or signs of concurrent PID. However, some limitations should be kept in mind. For example, as in our case, it is possible to have a false positive Murphy's sign that could lead to inappropriate examinations and even surgery. Murphy's sign has high sensitivity for acute cholecystitis (97\%) but very low specificity (48\%), and so must be interpreted in the clinical context ${ }^{[6]}$. Imaging, in particular ultrasonography, is very useful to restrict the differential diagnosis. Ultrasonographic signs of perihepatitis have been reported in small series of patients but their role is still debated ${ }^{[7-9]}$. 
The essential requirement for the diagnosis of FHCS is microbiological confirmation of the causative bacteria, which in order of frequency, are: C. trachomatis, N. gonorrhoeae, anaerobic bacteria, and various other bacteria including Mycoplasma genitalium and some gram-negative bacteria ${ }^{[10,11]}$. PCR techniques can detect very low amounts of $C$. trachomatis and $N$. gonorrhoeae in different biological specimens ${ }^{[12-15]}$. However, it is advisable to always make a bacterial smear in order to generate supplemental information (e,g. antibiogram).

Even if only one pathogen has been demonstrated, multiple bacteria are quite often responsible. Thus, antibiotic treatment should cover all possible bacteria involved according to the clinical context. The antibiotic regimen used in our hospital and derived from the CDC recommendations for PID, is shown in Table $2^{[1,15]}$.

Once the diagnosis has been made, extended STD screening is mandatory for all sexual partners who have had intercourse with the patient in the last 3 months according to a 'test and treat' strategy. The male partner frequently has more limited disease (mainly urethritis) and so treatment is shorter (Table 2).

Abdominal adhesions normally heal after appropriate antibiotic treatment, but are sometimes refractory and may cause chronic abdominal pain. Laparoscopic adhesiolysis may be advisable in such cases ${ }^{[1-3,7]}$.

Long-term follow up is useful to identify treatment failure, relapses and serious complications associated with PID (infertility, abdominal adhesions, chronic pain $)^{[1,3]}$.

\section{CONCLUSION}

Right upper quadrant abdominal pain is a common complaint in the primary care setting. In sexually active women with no gallstones and no definite cause for the pain, physicians should maintain a high index of suspicion for an ascending genital infection leading to perihepatitis. Although this clinical condition is quite uncommon, identification is very important because proper treatment can resolve symptoms and prevent the long-term complications associated with the often concomitant PID.

\begin{tabular}{|l|l|}
\hline Cholelithiasis & Pancreatitis \\
\hline Cholecystitis & Appendicitis \\
\hline Pleurisy & Rib Fracture \\
\hline Pneumonia & Endometriosis \\
\hline Pulmonary embolism & Subphrenic abscess \\
\hline Nephrolithiasis & Extrauterine pregnancy \\
\hline Pyelonephritis & Hepatitis \\
\hline Herpes zoster & Perforated ulcer \\
\hline
\end{tabular}

Table 1. Differential diagnosis

\begin{tabular}{|c|c|}
\hline Ambulatory regimen & $\begin{array}{c}\text { Ceftriaxone } 500 \text { mg i.m. single dose } \\
\text { plus } \\
\text { Doxycycline } 100 \mathrm{mg} \text { every } 12 \text { hours p.o. to complete } 14 \text { days } \\
\text { with or without } \\
\text { Metronidazole } 500 \text { mg every } 8 \text { hours p.o. to complete } 14 \text { days }\end{array}$ \\
\hline Partner's treatment & $\begin{array}{c}\text { Azitromycine } 1 \mathrm{~g} \text { single dose p.o. } \\
\text { or }\end{array}$ \\
& $\begin{array}{c}\text { Doxycycline } 100 \text { mg every } 12 \text { hours p.o. to complete } 7 \text { days } \\
\text { with or without } \\
\text { Ceftriaxone } 500 \text { mg i.m. single dose }\end{array}$ \\
\hline
\end{tabular}

Table 2. The antibiotic regimen used in our hospital 


\section{REFERENCES}

1. Peter NG, Clark LR, Jaeger JR. Fitz-Hugh-Curtis syndrome: a diagnosis to consider in women with right upper quadrant pain. Cleve Clin J Med 2004;71:233-239.

2. Fitz-Hugh T Jr. Acute gonococcic peritonitis of the right upper quadrant in women. JAMA 1934;102:2094-2096.

3. Ris HW. Perihepatitis (Fitz-Hugh-Curtis syndrome). A review and case presentation. J Adolesc Health Care 1984;5:272-276.

4. Curtis A. A cause of adhesions in the right upper quadrant. JAMA 1930;94:1221-1222.

5. Katzman DK, Friedman IM, McDonald CA, Litt IF. Chlamydia trachomatis Fitz-Hugh-Curtis syndrome without salpingitis in female adolescents. Am J Dis Child 1988;142:996998.

6. Singer AJ, McCracken G, Henry MC, Thode HC Jr, Cabahug CJ. Correlation among clinical, laboratory, and hepatobiliary scanning findings in patients with suspected acute cholecystitis. Ann Emerg Med 1996;28:267.

7. McCormack WM. Pelvic inflammatory disease. NEngl J Med 1994;330:115-119.

8. van Dongen PW. Diagnosis of Fitz-Hugh-Curtis syndrome by ultrasound. Eur J Obstet Gynecol Reprod Biol 1993; 50:159-162

9. Schoenfeld A, Fisch B, Cohen M, Vardy M, Ovadia J. Ultrasound findings in perihepatitis associated with pelvic inflammatory disease. J Clin Ultrasound 1992; 20:339-342.

10. Muller-Schoop JW, Wang SP, Munzinger J, et al. Chlamydia trachomatis as possible cause of peritonitis and perihepatitis in young women. Br Med J 1978;1:1022-1024.

11. Paavonen J, Saikku P, von Knorring J, Aho K, Wang SP. Association of infection with Chlamydia trachomatis with Fitz-Hugh-Curtis syndrome. J Infect Dis 1981;144:176.

12. Centers for Disease Control and Prevention. Sexually transmitted diseases treatment guidelines 2002. MMWR Recomm Rep 2002;51:1-78.

13. Ford GW et al. Pelvic Inflammatory Disease. Dis Mon 2016;62:301-305.

14. Lane AB, Decker CF. Chlamydia Trachomatis Infections. Dis Mon 2016;62:269-273.

15. Centers for Disease Control and Prevention. Recommendations for the Laboratory-Based Detection of Chlamydia trachomatis and Neisseria gonorrhoeae 2014. MMWR Recomm Rep 2014;63:1-21.

16. Workowski KA, Berman SM, Douglas JM Jr. Emerging antimicrobial resistance in Neisseria gonorrhoeae: urgent need to strengthen prevention strategies. Ann Intern Med 2008;148:606-613. 